\begin{tabular}{|c|c|}
\hline & Volume \& Issues Obtainable at The Women University Multan \\
\hline
\end{tabular}

\title{
Analysis the Impact of National Security Policy and Security Challenges on the Citizens of Pakistan \\ Khuram Shehzad ${ }^{1}$, Omer Farooq Zain ${ }^{2}$ \\ ${ }^{1} \mathrm{PhD}$ Scholar, Institute of Social Sciences (Pakistan Studies) Bahauddin Zakariya
}

University, Multan.omer_farooqzain@yahoo.com

${ }^{2}$ Chairman, Department Of International Relation, Bahauddin Zakariya University, Multan.

\section{ARTICLE DETAILS}

\section{History:}

Received:

November 10,2021

Review:

Accepted:

December 22, 2021

December 31, 2021

\section{Keywords:}

National Security Policy

Terrorism

Non-state Actors

National Action Plan

\section{DOI:}

10.52700/assap.v2i2.74

\section{ABSTRACT}

Pakistan is considered to below middle an income country in south Asia having a fragile and agro based economy. Pakistan is encountering various sociopolitical, geo political, socioeconomic and socio-religious issues and challenges which are halting its national security. . In this regard to counter above mentioned challenges of national security the pioneer defense and NSP (National Security Policy) followed soon after. In the absence of sufficient and particular literature on the subject of national security, the opening part of this research work will first highlight the overarching national interests of Pakistan secondly analysis of the current challenges which are obstructing Pakistan to achieve these national interests and identification of significant threats to national security. In the later part, a comprehensive examination of the current NSP (National Security Policy) of Pakistan and related documents will be done to answer the primary research question that whether this strategic manuscript addresses the major threats to the national security of Pakistan recognized in our research work as the fear of fundamental Islamist terrorism to the tourism industry overseas pressure and planned crime. (c) 2021 The Authors, Published by WUM. This is an Open Access Article under the Creative Common Attribution Non Commercial 4.0

Corresponding author's email address: khuramshezi196@gmail.com

\section{Introduction}

As the world becomes a global village the phenomenon of dynamics and uncertainty prevails in each country's homeland. In Pakistan, Since 2007 after the movement of democratic forces and lawyers against General Pervez Musharaf the civilian supremacy started to strengthen its supremacy and smooth democratic transitions have taken place by Ahmad, \& Rafiq, (2016) 
and Yamin (2015). However, the importance of electoral politics and the return of civilian supremacy is strengthened after two recent elections of 2013 and 2018. (International Crises Group, 2013; Haider, \& Ali, 2018; Ullah, Ahmad, \& Azim, 2020).

Pakistan is strategically a key player in South Asian politics due to its geographical position and nuclear power. Due to its strategic and geographic location, Pakistan is a hub for the majority of trade routes in South Asia and central Asia. Pakistan is confronts a broad scale of threats and challenges varying from political, armed forces, monetary, societal, information, communications, and its exclusive objective location Javed, \& Ismail, (2021) and Farzana, \& Tanweer, (2021). At the same time, extreme confusion in internal security challenges characterizes the democratic decade. The state capacity and morals of masses are affected due to terrorism and insurgency (Wilkinson, 2006; Lange, 2020).

An evaluation of the instruction followed to suitably tie the state course of action and deal with various considerable challenges that were not taken into account earlier. After 16/12/14 Army Public School incidence, a national consensus was developed to put on a national effort in order to combat and get rid of terrorism from Pakistan. while the NIP(National Internal Security Policy) 2014 proposed the wide-ranging course of action and long lasting structural adjustments in a different national institutions with definite, mostly realistic, measurable and finally time driven programs to restrain the curse of violence and brutality which had now resulting killing of naive school kids. On 24/12/14 parliament done legislation and approved a twenty Points National Action Plan to counter terrorism and extremism with consultation and consensus of all the stakeholders after approval of national security policy2014 (Ullah, Salim, \& Baloch, 2019; Khan, \& Saeed, 2018; Rumi, 2015). The basics to confront terrorism drive in the country are spelled out by the (NAP) National Action plan (NACTA, 2014).

The study will outline the plausible current challenges to Pakistan's national security and evaluate whether the National Internal Security Policy (NIP) 2014 counter these challenges. The key research problem for this investigation is: Does the major challenges and threats to Pakistanis national security are significantly addressed by the current national security plan.

The use of open source information and limited access to classified intelligence reports is a major limitation of this study. Several instructive credentials available regarding the national security policy of less populated countries which bear a resemblance to the situation in Pakistan would be of gigantic worth for the investigation of challenges to Pakistan national security. In order to put efficient and effective effort examination of these credentials and comparison to those of with Pakistan will be excluded from this research.

Subsequently, this research will highlight the historical perspective of Pakistan national security, literature review of the topic and significant evaluation of material available for this study. The next part will be methodology and then a detailed examination of each issue.

\subsection{Pakistan's National Security: A Historical Perspective}

The contemporary analysis of history is essentially required when there is a lack of national security strategy. Today Pakistan society is facing lots of challenges at national and international levels. At a national level, poverty, unstable economy, underperforming institutions tug of war between power centers, the doctrine of necessity, political immaturity and instability, multiple educational system and outdated curriculum, directionless foreign policy and selfish ruling class are the main challenges for Pakistan (Malik, 2018; Korai, Uddin, Memon, Ghaffar, \& Samad, 2021) ). On the other hand at the international level the 
India and Afghanistan coalition is working against Pakistan stability and sovereignty through insurgency in Baluchistan rest lessens in Karachi and safe houses safe passages and logistic support to terrorist's elements in order to abolish peace and destabilize Pakistan recent political developments (Bell, 2021; Sheikh, Shaikh, \& Price, 2012; Sunawar, 2014). Secondly, the United States of America is pursuing its plan to undermine Pakistan through exploiting its poor economic conditions and political instability in order to use Pakistan in so called war against terrorism. At the same time, the presence of non-state actors particularly those who are involved in violence driven activities has become an immense challenge. According to Phil Williams, these violent non state actors have become a persistent challenge to nation-states. These violent non state actors (VNA) always try to weaken the state and challenge the writ of the government. The birth and growth of these non- state actors are generally due to the bad governance of the state. These non- state actors and pressure groups develop atypical patterns of political, social and religious affiliations, like Manzoor Pashteen do under the flag of the Pashtun Tahafuz Movement (Aslam, \& Neads, 2021; Khan, 2018).

AS a result of these movements the ethnic groups like Mutahida Qaumi Movement(MQM) become the main reference points for political action, against the state (Mahmood, \& Farooq, 2019; Verkaaik, 2016). The role of state and executive comes under question when such groups are ingrained and root themselves deeper in the society? If their demands are genuine why state do not redress their grievances. Was it is a deliberate act of negligence and ignorance on the government part to allow them to become Monsters?

The Pakistani state has not done due to surveillance and proper border management over its borders with India Afghanistan and Iran frequent and hassle free movement of Afghan refugees is the main security concern. Pakistan repetitively asserts that due to the presence of geographically safe havens in FATA (Federally Administered Tribal Area) it is difficult to restrict the domestic and international militant settlements in these areas.

Historically Pakistan's government and law enforcement agencies largely remain unsuccessful to protect their citizens from threats of radical Islamist elements, communal and criminal violence (Saleem, (2019) and Azad, \& Haider. (2021). Moreover, Pakistani law enforcement agencies are regularly complicit in the crimes against Pakistan's citizens (Abbas, 2011; Azam, 2021; Mielke et al., 2021; Rahman, \& Shurong, 2021; Alimia, 2019).

Additionally, access to education, health and human services always remain an issue for Pakistan's citizens. Finally, the weak and less groomed civilian institutions have little or no sight of national foreign policy, military budgets and activities due to frequent military rules and hegemony of military establishment over these civil institutions. Despite the label of security state Pakistan seems to fall short on both fronts of Governance and Security.

In May 2011, the American and Chinese nationals were targeted by the Pakistani Taliban during a terrorist attack on a naval base in Karachi. It was a failure of law enforcement agencies that they were unable to anticipate this attack and terrorists easily reached the target which was not possible without assistance from within the navy. After this type of incident on civilian and military targets in recent years ignites a debate that Islamist militants can access Pakistani nuclear installations and Pakistan's nuclear program is not safe. 
Consequently, the international community and Pakistani civilians have concern over security measures by the government. These measures have critical implications for the citizens of Pakistan. Subsequently, the capacity and capability of law enforcement agencies were challenged during abbot a bad operation by the United States of America against Osama bin laden who had a long-standing affiliation with a group of extremists responsible for terrorist activities in the region and at the international level.

The 16/12/14 attack on APS PESHAWAR prove to be a game changer this incident cost Pakistan's lives 150 people's majority of which were innocent children. (Tehreke Taliban Pakistan) took the responsibility for these attacks. This unforgettable incident induces the government to revisit its national security policy. A week later, all political parties and military establishments consensually devise a twenty point national action plan to take stern action against all terrorist groups without any discrimination. Six months later, NAP proved to be as a hastily-conceived wish-list for public consumption throughout an instant of emergency than a rational strategy.

\section{Literature Review}

The analysis of challenges to Pakistan security and current measures to address these issues and challenges are the main focus of this study. The literature review focuses on two main areas.1 formulation of appropriate technique to evaluate the threats to Pakistan, literature review of the national security strategy of Pakistan.2in second part research question is answered with the help of important data and information. The classified records of assorted research house documents on history electronic media packages and present tactical concepts which may affect the law and order setting of Pakistan are included in this section. These areas are discussed in detail the below paragraphs.

Pakistan as a state having considerable challenges to its national security has very limited publications and research on the issue of national security as compared to other issues like worldwide environmental changes (global warming) and their impacts on Pakistan (Ripsman, \& Paul (2005) and Saleem (2015). The main factors for this lack of research on the issue of national security are (a). Less importance to national security challenges as compared to other challenges like environment. (b) There was a perception that national security is only the domain of armed forces. (c) it was considered taboo to discuss national security at the public level. These beliefs in the confidentiality and sacredness of national security drafts resulted in restricted access to senior civilian and military leaders only. This closed and restricted access and lack of debate on national security results in ultimate and inevitable loss to national security in the form of low efficiency and effectiveness (Ahmed, \& Brasted, 2021; Pawakapan, 2021)

The recent developments and open discussions on national security are the results of societal changes strengthen of democracy modernization and independence and the advent of social media and other mediums of communication. The 1973 Constitution of Pakistan ensures freedom of expression and freedom of media. The most important contributor to a national security strategy is the interest of the nation regarding overstretching of grand strategy. In the constitution of Pakistan, manifestos of mainstream political parties should capture the essence of a grand security strategy if there is no official strategy is available (Hussain, \& ZahraMalik. 2014). 
In order to counter the threats of terrorism and extremism a well directed, reformed, strengthened and independent criminal justice system is required (Smith, 1999). The democratic transition requires civilian rule but the only military effort to counter terrorism put the evolution of civil rule in Pakistan at risk. It is crystal clear that the use of only coercive measures to counter terrorism without structural reforms in the institutions and civil rule will not work there is a need to work on the root cause of terrorism and extremism because until these causes remained unnoticed the violent elements will continuously exploit the situation (Yusuf, 2008; Zeb, \& Ahmed, 2019). Structural violence and terrorism in the federally administered tribal areas of Pakistan. Civil Wars, 21(1), 1-24.). n. The continuous military establishment's efforts to keep civilian leadership under their influence will be a challenge to meaning full and long term structural adjustments and institutional reform Ullah, Ahmad, \& Azim, (2020). Yet the national political leadership is also responsible for failing to have a good working relationship with the military to make a collective effort for civil supremacy as a result, undermining its credibility and authority (Nikolas. 2011).

The PML (N) government take two vital steps in order to implement the national action plan(NAP)1.lift ban on death penalty imposed by Pakistan people's party government 2 . allow the establishment of special military courts through 21st constitutional amendment empowering military courts to trial all terrorist suspects including civilians. Since the start of their operations, military courts put to death almost 176 people for crimes unrelated to terrorism weakens constitutional protection and due process. on the other hand military establishment playing role in civil governance through representation in provincial apex committees. due to these legal covers and liberty military establishment got more leverage in marginalizing the civilian institutions in the process of Armed with new legal tools, the military has further marginalized civilian institutions in designing and enforcement of policy regarding counterterrorism (Khurshid, Ahmed, et al., 2013).

Regardless of claims to the contrary, the military establishment still distinguishes between good cop's bad cops. Good cops like Haqqani group and jammatul dawa are considered as strategic assets against Afghanistan and India respectively. While bad cops like TTP etc are considered a a threat to national security Khan, (2005) and Fayyaz, (2012).

In the absence of classified formal literature on national security, the information from secondary sources like media packages, surveys and analysis done by external independent institutions or organizations are crucial to this study Kissel, (2011). The work done by international think tanks, independent institutions and news agencies that are not oriented towards Pakistan may provide fruitful, neutral in-depth and independent analysis of national security challenges to Pakistan.

Three major emerging challenges are identified by this ESPAS report that will contribute to shaping the international environment by 2030. These challenges include an individual's sense of belongingness towards the human community, sustainable economic development against the dilemma of the scarcity of resources, inflation and poverty, climate change growing bays in interstate relationships and inadequate response of these states towards global demands. Pakistan as a part of the global community is greatly influenced by above stated political, social, economical and global challenges Wolf. (2021) and Qadeer. (2006). The factors of poverty, corruption, health issues, and climate change scarcity of water, wars, social and economic inequalities, the proliferation of weapons are the challenge world is perceived face these challenges out come of the phenomenon of globalization(global trends)2030. Pakistan 
due to its geostrategic and geo political importance is vulnerable to affect from these challenges (Hussain, \& Hussain, 2017; Sahir, \& Qureshi, 2007).

Globalization is the sum of an interdependent and interconnected networks of world countries due to the interconnection and interdependence among these countries influence each other (josephs Nye, 2008 and Zürn, (2013). The information revolution is the most significant change which contributed a lot in making the world a global village. Another view by Thomas Friedman is that due to an increase in interdependence and interconnection among countries a small deviation, distress, anxiety in one area can affect the whole system of the network. Geoeconomics is also influencing geopolitics. Free flow of information and revolution in information technology also pose threats to world security as fundamentalists, extremists and criminals also can use these technologies and can spread or propagate their activities at a massive levels in a short period which is the negative aspect of globalization. So the element of globalization cannot be neglected during the analysis of the security of any country especially in the case of countries like the Maldives which is a small country having insignificant resources and overdependence on the world economy Globalization can play important role in analyzing its security (Drori, 2008; Lu, 2021).

The brisk expansion of the economies of most populated countries like India and China have considerable impact and influence over regional security. The growing economy, the bulk of military deployments, rising middle class and unresolved issues like Kashmir, Tibet, Ladakh, etc require genuine attention while analyzing the security challenges of small countries in the region. According to Jared Diamond, the key factors like climate change, hostile neighbors' and social response to its problems contribute to the collapse of a society these factors will also remain in limelight in this research (Joaquin, \& Greitens, 2021).

\section{Literature Review Focuses on Formulating a Methodology}

Formulation of methodology is the main focus of this section of literature review literature on the process of security strategy formulation will also be part of this part. Some key literature on the subject is described in the following paragraphs.

The significance of diplomatic information, economic hegemony and role of the military establishment in a well-designed and result oriented national security is illustrated in the united states of America's army war college guide to national security policy and strategy edited by j.boone. The above-mentioned factors must remain in consideration while analyzing the challenges to the Maldive's national security.

The availability of sufficient, reliable, relevant and adequately analyzed information contributes towards the successful policy making process (Alan G. Stolberg) 2012. The policy making process starts with identification and framing of problems perhaps more importantly the principal guidelines suggested by Stolberg needs to keep in consideration during the analysis of Maldives national security challenges (J. Boone Bartholomes, Jr., ed., U.S.,2006)

The elements of national power and important premises concerning the theory of strategy must be kept into consideration: 1) the role of leadership and how leaders uses power and authority to attain defined goals and objectives determines the basics of a strategy. (2)The goals and objectives defined by leadership must be clear, realistic, attainable, and quantifiable. (3) endways and means in terms of strategy must be categorized and rightly 
balanced. (4) Strategy should directly approach the political idea. (5) Strategy must be dynamic, broad and hierarchal. (6) Internal and external factors which are vital and can affect a specific objective, concept and resource Strategy must be kept in view. (8) Must consider Risk return trade. The methodology that will be adhered to for this investigation uses the spirit of these vital grounds recognized earlier which suggests that strategy must be wideranging, coherent, clear, focused, and realistic, balanced and will pay attention to understand these important associations and promising areas of apprehension. An in-depth investigation of available data on Maldive's national security issues is required in the absence of classified documents.

\subsection{According to the Article in Jane's Intelligence Review}

The rumble in the current scenario of Islamist extremism in the restful Maldives has only seldom floated up, the most famous exception was bomb attack in September 2007 that result in injuries to several tourists. Some Maldivians traveled for jihadist training and return in the form of radical groups in the Maldivian island, some of them have connections with foreign elements. As these radical groups are largely are working to support their foreign counterparts in several external disputed areas the probability of more incidents on the island cannot be overruled. The $9 / 07$ bomb attack by the radical elements in the Maldives was the most horrible incident resulting in injuries to twelve the most terrible art of the incident was a video released of the 2007 incident by mussab sayyid who was the mastermind and executor of this suicide attack.

A Maldivian extremist was found involved in the attack on ISI headquarters in Lahore in May 2009 this incident shows the involvement of Maldivian nationals in terrorist activities in Pakistan. the report suggest that the extremism in the Maldives at the domestic level is the result of socioeconomic, socio religious changes. in addition to this, the report highlights the clash of thoughts and ideas between two school thoughts one secular or liberal attitude and behavior of western qualified students and second opposite to it conservative, radical, fundamentalist students belongs to Saudi Wahhabism and south Asian Deobandi school of thoughts. A government like India starts propaganda that Pakistan based organization Lashkar tayaba has its base camps in Maldivian island. Maldivian government accepts that government is facing the challenge of extremism but Maldives is not involved in any sort of terrorist activities.

Furthermore, the government is trying to cope up with the issue of extremism through religious education but if these programs fail to give fruitful results there is the threat of backfire by the fundamentalists who are supporting their counterparts in other countries. Maldives economy is based on tourism and foreign tourists predominantly non Muslims are its main source of earnings, so a potential radical assault on foreign tourists cannot be overruled. Ahmed Niyaz investigates potential threats and possible scenarios in his study "Terrorism and Extremism; A Threat to Maldives Tourism Industry". The study reveals that that 2008 Mumbai attacks by laskare tayiba and 2007sultan park bomb attack st new trends to target the tourism industry in order to create fear among foreign tourists. These types of incidents are the attempt to destroy a countries law and order situation and create fear in the minds of foreign investors and tourists which result in a halt in the economic growth of the victim country. 


\section{Conclusion and Policy Recommendation}

The threat of terrorism, human, weapon and drug trafficking, money laundering, activities of non-state elements and liberally associated criminals are the areas identified by Pakistani defense policymakers as a cause of serious concern to Pakistan national security. The use of the networked defense concept is absent in formulating national defense reasons are lack of cooperation, confidence and coordination among state institutions tug of war for supremacy between civil and military establishments. Although a lot of discussion on Pakistan's national security challenges is done still there is a need to prioritize and to design a comprehensive spectrum of threats identified. For example, maritime security agency has lack capital and human resources, coordination among other agencies and human intelligence.

Due to democratization concerns over Defense and National Security by defense institutions are increased. The role $\mathrm{f}$ a civilian is not adequate in identifying challenges to national security all the things revolve around the military. Although National security policy identifies possible challenges and threats to national security this document does not prioritize the threats or provide comprehensive solution and intended focus to the national security apparatus accordingly.

It is recommended that there is a need national approach in developing national security policy by engaging all stake holders power centers government or nongovernment institutions in the course of identification and prioritization of the threats to the national security of Pakistan. In this regard, there is a need for visionary, committed and dedicated leader who must put national interest on topmost priority comparison to personal or political benefit.

As for the analysis, it is suggested that refinement and prioritization of the challenges to national security will be imperative to spotlight the sparse resources of the state. The main challenges acknowledged in this limited analysis tilt towards an approach paying attention to protect the scarce resources of the country.

\section{References}

Ahmad, I., \& Rafiq, A. (Eds.). (2016). Pakistan's democratic transition: Change and persistence. Taylor \& Francis.

Alimia, S. (2019). Performing the Afghanistan-Pakistan border through refugee ID cards. Geopolitics, 24(2), 391-425.

Asia Report. (2015). Revisiting Counter-terrorism Strategies in Pakistan: Opportunities and Pitfalls, International Crisis Group Avenue Louise 1491050 Brussels, Belgium.

Aslam, W., \& Neads, A. (2021). Renegotiating societal-military relations in Pakistan: the case of the Pashtun Tahafuz Movement. Democratization, 28(2), 265-284.

Azad, T. M \& Haider. M. W (2021). The Threat of Post 9/11 Sectarian Violence to the National Integration of Pakistan: A Critical Appraisal. 03(1). 23-38.

Azam, R. I. (2021). Analysis of Pakistan's policy towards Afghan refugees: a legal perspective.

Baldwin. A. (2005). Security Studies and the End Of Cold War, World Politics 48, 117-41.

Baldwin.A. (1997). The Concept of Security, Review of International Studies, 23-26 Copyright British International Studies Association.

Bell, L. N. (2021). Targets of Terror: Contemporary Assassination. Rowman \& Littlefield.

Cheema. P. (2014). Security Threats Confronting Pakistan, Security Outlook of the Asia Pacific Countries and Its Implications for the Defense Sector, 127-140. 
Cheema. P. (2014). Security Threats Confronting Pakistan, Security Outlook of the Asia Pacific Countries and Its Implications for the Defense Sector, 127-140.

Christine. F. (2012). Security Sector Governance in Pakistan: Progress, But Many Challenges Persists, The Centre for International Governance Innovation SSR Issue Papers: No.5.

Drori, G. S. (2008). Institutionalism and globalization studies. The Sage handbook of organizational institutionalism, 449-472.

Farzana, A., \& Tanweer, K. (2021). Pakistan China relations in the Emerging Dynamics of Power in South Asia. Amazonia Investiga, 10(38), 11-19.

Fayyaz, S. (2012). Pakistan response towards terrorism: a case study of Musharraf regime (Doctoral dissertation, University of Birmingham).

Haider, S. K., \& Ali, S. S. (2018). Impact of Benazir Bhutto Death on Performance of PPP and Electoral Politics of Pakistan 2008-2013. Pakistan Vision, 19(1).

Human Rights Development Report. (1994). New Dimensions of Security, UNDP, UNDP, 2013).

http://hdr.undp.org/en/media/hdr_1994_en_chap2.pdf (accessed October 3,

Hussain, F., \& Hussain, M. (2017). China-Pak economic corridor (CPEC) and its geopolitical paradigms. International Journal of Social Sciences, Humanities and Education, 1(2), 79- 95.

Hussain, S. M., \& Zahra-Malik, M. (2014). Political instability and its implications for an effective national counterterrorism policy in Pakistan. Pakistan's counterterrorism challenge, 98-100.

Hussain. W. (2010, September 10). Security Challenges To Pakistan, http://www.cmcpk.net/2013/09/security-challenges-to-pakistan.

István. K., \& Krisztina. Z. (2008). Safety and Security in the Age of Global Tourism (The Changing Role and Conception of Safety and Security in Tourism). Applied Studies in Agribusiness and Commerce - APSTRACT Agroinform Publishing House, Budapest.

Javed, H. M., \& Ismail, M. (2021). CPEC and Pakistan: Its Economic Benefits, Energy Security and Regional Trade and Economic Integration. Chinese Political Science Review, 6(2), 207-227.

Khalid. I. (2013). Restructuring the Image of Pakistan: Internal Challenges and External Pressures, Dialogue, Peshawar.

Khan, A. U. (2005). The terrorist threat and the policy response in Pakistan. Stockholm International Peace Research Institute.

Khan, A., \& Saeed, A. (2018). National Action Plan: Performance so far. Conflict and Peace Studies, 89.

Khurshid Ahmed et al., (2013) Agenda before the Nation 2013 and Beyond, Policy Perspectives 10 no. 1,33 .

Korai, A. G., Uddin, I., Memon, I. A., Ghaffar, A., \& Samad, A. (2021). Pakistani Minorities: Are They Protected By Or Persecuted By The Constitution?. PalArch's Journal of Archaeology of Egypt/Egyptology, 18(4), 7064-7076.

Krippendorff, Klaus (2004). Content Analysis: An Introduction to Its Methodology (2nd ed.). Thousand Oaks, CA: Sage. p. 413.

Lange, M. (2020). 3. State Formation, Consolidation, and the Security Challenge. In South Asia's Weak States (pp. 51-72). Stanford University Press.

Lu, J. (2021). Institutional predicament and reform of global governance. In Chinese Perspectives on Global Governance and China (pp. 117-137). Brill. 
Mahmood, A., \& Farooq, S. (2019). Transformation from Ethnicity to Violence: A Case Study of Mutahida Qaumi Movement, 1983-2013. Pakistan Journal of History and Culture, 40(1).

Malik, S. (2018). Security Sector Reforms in Pakistan: Significance, Challenges and Impediments. Strategic Studies, 38(3).

Maria, S.(2014).Need for a Paradigm Shift in Security: Adopting Human Security in Pakistan, IPRI Journal XIV, no. 2 (pp. 79-97).

Michael. K.(2011). India's Contemporary Security Challenges (Ed.), Woodrow Wilson International Center for Scholars, Washington D.C.

Mielke, K., Shahid, M. N., Khatana, A. R., Ahmed, Z., Irshad, A., Kiran, S., .. \& Javed, M. M. (2021). Figurations of displacement in and beyond Pakistan: empirical findings and reflections on protracted displacement and translocal connections of Afghans.

Naheed. A. C. (.2014). Pakistan's National Security: An Analytical Study,94 J. Asian Dev.Stud,Vol.3,Issue3,ISSN2304-375X.

Naheed. A. C. (.2014). Pakistan's National Security: An Analytical Study,94 J. Asian Dev.Stud,Vol.3,Issue3,ISSN2304-375X.

Nikolas. T. (2011). Problematizing human security: a general/contextual conceptual approach, $\quad$ Southeast European and Black Sea Studies 11, no. 4, 354.

Pawakapan, P. (2021). Infiltrating Society: The Thai Military's Internal Security Affairs. ISEAS- Yusof Ishak Institute.

Qadeer, M. (2006). Pakistan-social and cultural transformations in a Muslim Nation. Routledge.

Rahman, S. U., \& Shurong, Z. (2021). Governing through Informal Mechanisms: Military Control over State Institutions in Pakistan. Asian Survey, 61(6), 942-970.

Ripsman, N. M., \& Paul, T. V. (2005). Globalization and the national security state: a framework for analysis. International Studies Review, 7(2), 199-227.

Rumi, R. (2015). Charting Pakistan's internal security policy. Washington DC: United States Institute of Peace.

Safi. S. (2014).National Security Policy: an Analysis, PILDAT, Islamabad.

Sahir, M. H., \& Qureshi, A. H. (2007). Specific concerns of Pakistan in the context of energy security issues and geopolitics of the region. Energy Policy, 35(4), 2031-2037.

Saleem, A. (2015, June). Siachen conflict between India and Pakistan: how politics and national security trumps environmental concerns. In Spaces of Scholarship and Practice in Environmental Communication: The Conference on Communication and Environment (pp. 11- 14).

Saleem, R. M. A. (2019). Has the Pakistani State Taken a Post-Islamist Turn? Pakistan Horizon, 72(3).

Sheikh, M. K., Shaikh, F., \& Price, G. (2012). Pakistan: Regional rivalries, local impacts (No. 2012: 12). DIIS Report.

Smith. S. (1999). The increasing insecurity of security studies: Conceptualizing security in the last twenty years, Contemporary Security Politics 20 no. 3, 77.

Sunawar, L. (2014). THE 2014 Us Withdrawal-An Unsettled Quagmire for Pakistan. Editorial Board, 32(4), 95.

Ullah, W., Salim, A., \& Baloch, Z. (2019). Analyzing the Counter Terrorism Policies of Pakistan. Dialogue (1819-6462), 14(4).

Ullah, Y., Ahmad, M., \& Azim, S. W. (2020). Politics of Protest in Pakistan: Causes and Features of the PTI (2014) Dharna in Islamabad, Pakistan. Global Strategic \& Security Studies Review, V(I), 23-31. 
UNDP. (1994). Human Development Report,http://hdr.undp.org/en/media/hdr 1994_en_chap2.pdf(accessed March 3, 2016).

UNO (2004). A more secure world: Our Share Responsibility, Report of the High-level Panel on Threats, Challenges and Change.

Verkaaik, O. (2016). Violence and ethnic identity politics in Karachi and Hyderabad. South Asia: Journal of South Asian Studies, 39(4), 841-854.

Wilkinson, P. (2006). Terrorism versus democracy: The liberal state response. Routledge.

Wolf, S. O. (2021). China-Pakistan Economic Corridor of the Belt and Road Initiative. Springer.

Yamin, S. (2015). Pakistan: National Security Dilemmas and Transition to Democracy. Journal of Asian Security and International Affairs, 2(1), 1-26.

Yusuf, M. (2008). Prospects of youth radicalization in Pakistan. Brookings, Analysis Paper, 14(7), 1-27.

Zeb, K., \& Ahmed, Z. S. (2019). Structural violence and terrorism in the federally administered tribal areas of Pakistan. Civil Wars, 21(1), 1-24. 